\title{
MENINGKATKAN KEMAMPUAN REPRESENTASI MATEMATIS SISWA MENGGUNAKAN MODEL PEMBELAJARAN CONNECTING, ORGANIZING, REFLECTING, EXTENDING (CORE)
}

\author{
Dyna Darozatun ${ }^{1}$, Nur Eva Zakiah², Ida Nuraida ${ }^{3}$ \\ 1MTs Karangpari, Jl. Desa Karangpari No. 08, Karangpari, Rancah, Ciamis, Indonesia \\ 2,3Program Studi Pendidikan Matematika, Universitas Galuh, Jl. R. E. Martadinata No.150, Ciamis, Indonesia \\ Email: nurevazakiah@unigal.ac.id
}

\begin{abstract}
This research is motivated by the importance of mathematical representation ability that must be possessed by each student. One model that can be used to improve students' mathematical representation skills is the Connecting, Organizing, Reflecting, Extending (CORE) learning model. This study aims to find out the difference in mathematical representation skills between students who use core learning models and students who use direct learning models. The research method used is quasi experimental with the nonequivalent control group design. Data analysis techniques using Mann-Whitney non-parametric tests. The population is all students of grade VIII SMP Negeri 1 Baregbeg which consists of eleven classes with sampling using purposive sampling techniques. The selected sample is class VIII-J as an experimental class of 29 people and class VIII-I as a control class of 28 people. The instrument used is a test instrument that is a test of mathematical representation ability. The subject matter presented as material is cubes and beams. The results of this study showed that there are differences in mathematical representation ability between students who use core learning models (high criteria) and students who use direct learning models (medium criteria).
\end{abstract}

Keywords: Connecting, Organizing, Reflecting, Extending (CORE) learning model, mathematical representation ability

\begin{abstract}
ABSTRAK
Penelitian ini dilatarbelakangi oleh pentingnya kemampuan representasi matematis yang harus dimiliki oleh setiap siswa. Salah satu model yang dapat digunakan untuk meningkatkan kemampuan representasi matematis siswa adalah model pembelajaran Connecting, Organizing, Reflecting, Extending (CORE). Penelitian ini bertujuan untuk mengetahui perbedaan peningkatan kemampuan representasi matematis antara siswa yang menggunakan model pembelajaran CORE dengan siswa yang menggunakan model pembelajaran langsung. Metode penelitian yang digunakan adalah quasi experimental dengan the nonequivalent control group design. Teknik analisis data menggunakan uji nonparametrik Mann-Whitney. Populasi adalah semua siswa kelas VIII SMP Negeri 1 Baregbeg yang terdiri dari sebelas kelas dengan pengambilan sampel menggunakan teknik purposive sampling. Adapun sampel yang terpilih adalah kelas VIII-J sebagai kelas eksperimen sebanyak 29 orang dan kelas VIII-I sebagai kelas kontrol sebanyak 28 orang. Instrumen yang digunakan adalah instrumen tes yaitu tes kemampuan representasi matematis. Pokok bahasan yang disajikan sebagai bahan materi adalah kubus dan balok. Hasil penelitian ini menunjukkan bahwa terdapat perbedaan peningkatan kemampuan representasi matematis antara siswa yang menggunakan model pembelajaran CORE (kriteria tinggi) dengan siswa yang menggunakan model pembelajaran langsung (kriteria sedang).
\end{abstract}

Kata kunci: Model pembelajaran Connecting, Organizing, Reflecting, Extending (CORE), kemampuan representasi matematis

Cara sitasi: Darozatun, D., Zakiah, N. E., \& Nuraida, I. (2021). Meningkatkan Kemampuan Representasi Matematis Siswa Menggunakan Model Pembelajaran Connecting, Organizing, Reflecting, Extending (CORE). J-KIP (Jurnal Keguruan dan IImu Pendidikan), 2 (1), 105-114. 


\section{PENDAHULUAN}

Menurut NCTM (National Council of Teacher Mathematics) (2000) terdapat lima kemampuan matematis yang harus dikuasai oleh siswa dalam pembelajaran matematika, meliputi kemampuan: (1) pemecahan masalah (problem solving); (2) penalaran dan pembuktian (reasoning and proof); (3) komunikasi (communication); (4) koneksi (connection); dan (5) representasi (representation). Siswa yang telah mempelajari matematika diharapkan memiliki kompetensi mencakup sikap, pengetahuan, dan keterampilan (Zakiah \& Fajriadi, 2020a). Salah satu kemampuan yang perlu dimiliki siswa tersebut adalah kemampuan representasi matematis.

Representasi merupakan salah satu kemampuan yang sangat diperlukan dan perlu dikembangkan karena digunakan sebagai dasar dalam pembelajaran matematika. Pernyataan tersebut sesuai dengan ungkapan Jones \& Knut (Arnidha, 2016) bahwa terdapat beberapa alasan perlunya kemampuan representasi, yaitu: kemampuan dasar untuk membangun konsep dan berpikir matematis, serta untuk memiliki kemampuan pemahaman konsep yang baik dan dapat digunakan dalam pemecahan masalah. Representasi adalah pusat untuk belajar matematika. Siswa dapat mengembangkan dan memperdalam pemahaman mereka tentang konsep matematika dan hubungan yang mereka buat, membandingkan, dan menggunakan representasi yang bervariasi.

Beberapa penelitian yang telah dilakukan, menjelaskan kesalahan-kesalahan yang dilakukan siswa dalam kemampuan representasi. Penelitian yang dilakukan oleh Legi (2008) menyatakan bahwa siswa dengan kemampuan rendah, kesulitan dalam menciptakan dan menggunakan representasi simbolik dan gambar. Selanjutnya penelitian yang dilakukan Suryowati (2015) mengungkapkan bahwa siswa masih belum memahami bagaimana merepresentasikan masalah dunia nyata ke dalam masalah matematika yang representatif.

Masalah rendahnya kemampuan representasi juga terjadi di salah satu SMP di Kabupaten Ciamis, dari hasil wawancara dengan guru mata pelajaran matematika di SMP tersebut diperoleh informasi bahwa siswa ketika dihadapkan dengan sebuah soal yang memerlukan kemampuan representasi mereka kesulitan untuk menginterpretasikannya ke dalam bentuk gambar, persamaan atau ekspresi matematis, serta teks tertulis sehingga menyebabkan kemampuan representasi matematis siswa masih tergolong rendah.

Salah satu penyebab rendahnya kemampuan representasi matematis siwa adalah masih kurang efektifnya pembelajaran dimana siswa masih berperan pasif selama proses pembelajaran sehingga tidak dapat mengembangkan kemampuan representasi matematisnya. Permasalahan serupa diketahui bahwa siswa cenderung kurang diberikan kesempatan untuk memberikan alternatif solusi dalam menyelesaikan permasalahan, soal-soal yang diberikan masih close problem yakni tipe masalah yang diberikan mempunyai cara dan jawaban yang tunggal (Zakiah, 2017). Temuan lain di lapangan bahwa pembelajaran matematika masih cenderung berfokus pada buku teks, masih sering dijumpai guru matematika terbiasa mengajar dengan menggunakan langkah-langkah pembelajaran seperti: menyajikan materi pembelajaran, memberikan contoh-contoh soal dan meminta siswa mengerjakan soal-soal latihan yang terdapat dalam buku teks yang mereka gunakan dalam mengajar dan membahasnya bersama siswa (Arnidha, 2016).

Dari permasalahan tersebut maka perlu adanya inovasi untuk mengoptimalkan proses pembelajaran agar menjadi bermakna bagi siswa, menyenangkan, serta pembelajaran yang dapat mendorong siswa untuk mengkonstruk serta mengembangkan pengetahuan yang telah dimiliki sebelumnya (Zakiah et al., 2019). Salah satu model pembelajaran yang menuntut siswa untuk berperan aktif dalam proses pembelajaran sehingga dapat merangsang peningkatan kemampuan representasi matematis adalah model pembelajaran Connecting, Organizing, Reflecting, dan Extending (CORE). Model pembelajaran CORE adalah sebuah model yang mencakup empat proses yaitu Connecting, Organizing, Reflecting dan Extending. Menurut Calfee et al. (Dwijayanti \& Kurniasih, 2014) menyatakan bahwa model pembelajaran CORE adalah model pembelajaran yang mengharapkan siswa dapat mengkonstruksi pengetahuannya sendiri dengan cara menghubungkan (connecting) dan mengorganisasikan (organizing) pengetahuan baru dengan pengetahuan lama 
kemudian memikirkan konsep yang sedang dipelajari (reflecting) serta diharapkan siswa dapat memperluas pengetahuan mereka selama proses belajar mengajar berlangsung (extending).

Pada model pembelajaran CORE ini, aktivitas berpikir sangat ditekankan kepada siswa. Siswa dituntut untuk dapat mengolah segala informasi yang telah didapatnya. Melalui kegiatan mengoneksikan konsep lama dan konsep baru, siswa dilatih untuk mengingat informasi lama dan menggunakan informasi atau konsep baru. Kegiatan mengorganisasikan ide-ide dapat melatih siswa untuk mengorganisasikan dan mengelola informasi yang telah dimilikinya. Kegiatan refleksi merupakan kegiatan memperdalam, menggali informasi untuk memperkuat konsep yang telah dimilikinya. Kegiatan extending siswa dilatih untuk mengembangkan, memperluas informasi dan dapat menemukan konsep serta informasi baru yang bermanfaat. Sehingga melalui tahapan pembelajaran tersebut kemampuan siswa pada aspek representasi matematis dapat berkembang dengan baik karena siswa diberikan kesempatan untuk mengkontruksi pengetahuannya melalui pengungkapan gagasan maupun ide-ide dari suatu permasalahan yang diberikan oleh guru.

Berdasarkan latar belakang di atas maka tujuan penelitian ini adalah untuk mengetahui perbedaan peningkatan kemampuan representasi matematis antara siswa yang menggunakan model pembelajaran Connecting, Organizing, Reflecting, Extending (CORE) dengan siswa yang menggunakan model pembelajaran langsung.

\section{METODE PENELITIAN}

Metode penelitian yang digunakan dalam penelitian ini adalah quasi experimental. Desain penelitian menggunakan the nonequivalent pretest-posttest control group design yang dilustrasikan sebagai berikut (Sugiyono, 2016):

$$
-\underline{O}-\underline{X}-\underline{O}--
$$

\section{Gambar 1. Desain Penelitian}

Keterangan:

$---=$ pemilihan sampel tidak secara random

$X=$ Pembelajaran menggunakan model pembelajaran CORE

$\mathrm{O}=$ pretes/postes kemampuan representasi matematis

Populasi dalam penelitian ini adalah seluruh siswa kelas VIII SMP Negeri 1 Baregbeg Tahun Pelajaran 2017/2018. Sampel dipilih dengan teknik purposive sampling, diperoleh sebanyak dua kelas yaitu kelas VIII-J sebagai kelas eksperimen sebanyak 29 orang dan kelas VIII-I sebagai kelas kontrol sebanyak 28 orang. Metode pengumpulan data yang dilakukan adalah metode tes. Soal yang diberikan adalah soal berbentuk uraian yang sebelumnya telah diujicobakan. Tes dilakukan sebanyak dua kali yaitu pretes dan postes yang bertujuan untuk memperoleh data kemampuan representasi matematis sebelum dan setelah pembelajaran menggunakan model pembelajaran CORE pada kedua kelas.

Analisis data terbagi menjadi dua yakni analisis data pretes dan analisis data N-Gain. Analisis data pretes dilakukan untuk melihat bahwa kedua kelas memiliki kemampuan representasi matematis awal yang sama. Analisis data pretes ini meliputi uji normalitas, uji homogenitas, dan uji kesamaan dua rerata yaitu uji-t. Sedangkan analisis data $\mathrm{N}$-Gain dilakukan untuk melihat peningkatan kemampuan representasi matematis siswa pada kedua kelas. Analisis data N-Gain meliputi uji normalitas, dan uji perbedaan dua rerata yaitu uji mann-whitney.

Prosedur penelitian secara garis besar dilakukan melalui empat tahap yaitu: persiapan, pelaksanaan, analisis data dan penarikan kesimpulan. 


\section{HASIL DAN PEMBAHASAN}

Penelitian dilaksanakan pada semester genap Tahun Pelajaran 2017/2018 terhadap siswa kelas VIII SMP Negeri 1 Baregbeg pada materi Kubus dan Balok dengan tujuan untuk mengetahui perbedaan peningkatan kemampuan representasi matematis siswa antara yang menggunakan model pembelajaran CORE dengan siswa yang menggunakan model pembelajaran langsung.

Sebelum dilakukan penelitian kedua kelompok diberi pretes untuk mengetahui kemampuan representasi matematis awalnya. Selama penelitian berlangsung kelompok pertama atau kelas eksperimen diberi perlakuan yaitu pembelajaran dengan model pembelajaran CORE dan kelompok yang lain atau kelas kontrol menggunakan model pembelajaran langsung. Selanjutnya diakhir penelitian kedua kelas diberi postes untuk melihat kemampuan representasi matematis akhirnya.

Statistik deskriptif data pretes kemampuan representasi matematis siswa untuk kedua kelas sampel disajikan dalam Tabel 1.

\section{Tabel 1. Statistik Deskriptif Data Pretes Kemampuan Representasi Matematis Siswa

\begin{tabular}{ccc}
\hline \multirow{2}{*}{ Statistik Deskriptif } & \multicolumn{2}{c}{ Pretes } \\
& Eksperimen & Kontrol \\
\hline Jumlah Siswa & 29 & 28 \\
Minimum & 38 & 25 \\
Maksimun & 68 & 65 \\
Rata-rata & 53,03 & 49,36 \\
\hline
\end{tabular}

Setelah dilakukan perhitungan statistik deskriptif untuk melihat gambaran umun data pretes, kemudian dilakukan pengolahan statistik inferensial untuk melihat kemampuan representasi matematis awal kedua kelas. Uji normalitas menggunakan uji Shapiro-Wilk diperoleh nilai signifkansi $0,168>0,05$ untuk kelas eksperimen dan 0,442>0,05 untuk kelas kontrol. Artinya baik untuk kelas eksperimen maupun kelas kontrol berdistribusi normal. Kemudian dilakukan uji homogenitas dengan uji Lavene Statistic diperoleh nilai signifikansi 0,880 >0,05, artinya bahwa kedua kelas memiliki varians yang sama. Karena data berdistribusi normal dan homogen maka selanjutnya dilakukan uji kesamaan dua rerata dengan menggunakan uji-t dengan diperoleh nilai signifikansi 0,181 $>0,05$. Hasil ini menunjukkan bahwa $\mathrm{H}_{0}$ diterima, artinya tidak terdapat perbedaan kemampuan awal representasi matematis antara kelas eksperimen dan kelas kontrol. Sehingga dapat disimpulkan bahwa kelas eksperimen dan kelas kontrol memiliki kemampuan representasi matematis awal yang sama.

Data yang digunakan untuk mengetahui peningkatan kemampuan representasi matematis adalah data gain ternormalisasi ( $\mathrm{N}$-Gain). Peningkatan tersebut dihitung dengan menggunakan rumus gain ternormalisasi menurut Meltzer (Elida, 2012).

$$
N-\text { Gain }=\frac{\text { skor postes }- \text { skor pretes }}{\text { Skor Maksimum Ideal }- \text { pretes }}
$$

Sebelum dilakukan pengujian terhadap data hasil $N$-Gain dilakukan terlebih dahulu perhitungan statistik deskriptif dengan hasil disajikan dalam Tabel 2.

Tabel 2. Statistik Deskriptif Data N-Gain Kemampuan Representasi Matematis Siswa

\begin{tabular}{ccc}
\hline \multirow{2}{*}{ Statistik Deskriptif } & \multicolumn{2}{c}{$N$-Gain } \\
& Eksperimen & Kontrol \\
\hline Jumlah Siswa & 29 & 28 \\
Minimum & 0,152 & 0,080 \\
Maksimun & 1,00 & 0,743 \\
Rata-rata & 0,727 & 0,369 \\
\hline
\end{tabular}

Setelah dilakukan perhitungan statistik deskriptif kemudian dilakukan perhitungan statistik inferensial untuk melihat perbedaan peningkatan kemampuan representasi matematis siswa kedua 
kelas sampel. Uji normalitas menggunakan uji Shapiro-Wilk diperoleh nilai signifkansi $0,022<0,05$ untuk kelas eksperimen dan 0,078 >0,05 untuk kelas kontrol. Artinya skor $N$-Gain kelas eksperimen tidak berdistribusi normal sedangkan skor $\mathrm{N}$-Gain kelas kontrol berdistribusi normal. Karena data $\mathrm{N}$ Gain kelas eksperimen tidak berdistribusi normal maka selanjutnya analisis data uji perbedaan dua rerata menggunakan uji Mann-Whitney, diperoleh hasil nilai signifikansi $0,00<0,05$ artinya $H_{0}$ ditolak. Sehingga dapat disimpulkan bahwa terdapat perbedaan peningkatan kemampuan representasi matematis antara siswa yang menggunakan model pembelajaran CORE dengan siswa yang mengunakan model pembelajaran langsung.

Berdasarkan Tabel 2 mengenai deskripsi skor $\mathrm{N}$-Gain kemampuan representasi matematis siswa, diketahui bahwa rata-rata skor $\mathrm{N}$-Gain kelas eksperimen adalah 0,727 yang menunjukkan bahwa kualitas peningkatan kemampuan representasi matematis tergolong tinggi. Sedangkan ratarata $\mathrm{N}$-Gain siswa kelas kontrol adalah 0,369 yang menunjukkan bahwa kualitas peningkatan kemampuan representasi matematis tergolong sedang. Untuk lebih jelasnya, kualitas peningkatan kemampuan representasi matematis disajikan dalam Tabel 3.

Tabel 3. Kualitas Peningkatan Kemampan Representasi Matematis Siswa

\begin{tabular}{ccc}
\hline Kelas & Rata-rata & Kualitas Peningkatan \\
\hline Eksperimen & 0,727 & Tinggi \\
Kontrol & 0,369 & Sedang \\
\hline
\end{tabular}

Pada penelitian ini tahapan model pembelajaran CORE sesuai dengan tahapan model pembelajaran CORE dalam Shoimin (2014), terdiri dari persiapan, connecting, organizing, pembagian kelompok, reflecting, dan extending. Dalam pelaksanaannya pada fase persiapan guru membuka pembelajaran dengan kegiatan yang menarik bagi siswa, dalam hal ini karena jam jadwal pelajaran matematika pada kelas eksperimen ada pada jam ke 5 dan ke 6 dimana kondisi siswa sudah tidak dalam keadaan yang masih semangat maka peneliti melakukan ice breaking yang bertujuan untuk mengecek konsentrasi dan menumbuhkan semangat belajar siswa. Kemudian pada fase connecting ini pertama-tama guru membagikan bahan ajar terkait materi yang akan dibahas. Bahan ajar dibagikan kepada setiap siswa. Dalam bahan ajar tersebut terdapat beberapa petunjuk yang mendorong siswa untuk mengkoneksikan materi yang sedang dipelajari dengan materi yang sudah dipelajari. Lalu pada fase organizing guru membimbing siswa untuk mengorganisasikan ideidenya pada materi dengan mengisi bahan ajar. Siswa diajak untuk mengorganisasikan informasi yang diperolehnya seperti konsep apa yang diketahui, konsep apa yang dicari serta keterkaitan antar konsep apa saja yang ditemukan pada tahap connecting untuk dapat membangun pengetahuan barunya. Apabila siswa mampu memahami serta mengaitkan antar konsep matematika maka pemahaman konsep yang dimiliki siswa akan lebih dalam serta bertahan lama (Nurhayati et al., 2020).

Selanjutnya siswa dibagi menjadi beberapa kelompok yang beranggotakan 4-5 orang. Kemudian pada fase reflecting guru membimbing siswa berdiskusi bersama kelompoknya untuk memikirkan kembali, mendalami dan menggali informasi yang sudah didapat. Anggota kelompok yang sudah paham terhadap materi diminta oleh guru untuk menjelaskan kepada anggota kelompok lain yang belum mengerti. Diakhir fase reflecting ini guru memastikan bahwa setiap siswa sudah paham terhadap materi dengan mengajukan beberapa pertanyaan. Terakhir fase extending dijadikan fase pengembangan dan perluasan pengetahuan siswa. Untuk mengembangkan kemampuan siswa pada fase ini setiap siswa diberi LKS yang berisi soal-soal mengenai materi yang telah diberikan untuk dikerjakan bersama kelompoknya. Siswa diharapkan dapat memperluas pengetahuan dengan cara mengerjakan soal-soal yang berhubungan dengan konsep yang dipelajari. Setelah setiap kelompok selesai mengerjakan LKS, guru memilih beberapa kelompok untuk maju dan mempresentasikan hasil pengerjaannya. Kelompok yang terpilih kemudian mengutus satu perwakilan sementara kelompok lain menyimak dan memberi tanggapan. Selama 
proses presentasi berlangsung guru memberikan konfirmasi terhadap jawaban siswa dan diakhir kegiatan extending guru meminta siswa untuk menyimpulkan hasil kerja mereka. Melalui aktivitas kelompok mampu meningkatkan motivasi dan memfasilitasi siswa untuk secara optimal memperoleh pembelajaran yang bermakna untuk hasil yang lebih baik (Zakiah et al., 2020b), serta membantu siswa yang lemah untuk membangun kepercayaan diri (Zakiah et al., 2020c).

Berdasarkan uraian yang sudah dijelaskan mengenai implementasi model pembelajaran CORE terlihat bahwa model pembelajaran CORE dapat menunjang peningkatan kemampuan representasi matematis siswa. Hal ini dipertegas dari hasil uji perbedaan dua rerata (Uji MannWhitney) $\mathrm{N}$-Gain bahwa $\mathrm{H}_{0}$ ditolak yang artinya terdapat perbedaan peningkatan kemampuan representasi matematis antara siswa yang menggunakan model pembelajaran pembelajaran Connecting, Organizing, Reflecting, Extending (CORE) dengan siswa yang menggunakan model pembelajaran langsung.

Pada penelitian ini, kemampuan representasi matematis siswa diukur berdasarkan kemampuan siswa dalam mengerjakan pretes dan postes kemampuan representasi matematis sesuai dengan indikator dan pedoman penskoran kemampuan representasi matematis. Kemampuan representasi matematis yang diteliti meliputi: (1) Aspek representasi teks tertulis yang berupa kemampuan untuk membuat situasi masalah yang diberikan, menulis interpretasi dari suatu representasi dan menulis langkah-langkah penyelesaian masalah matematis dekan kata-kata; (2) Aspek representasi gambar yang berupa kemampuan untuk menggambar pola-pola geometri, dan membuat gambar bangun pola geometri untuk memperjelas masalah dan memfasilitasi penyelesaian; dan (3) Aspek representasi persamaan atau ekspresi matematis yang berupa kemampuan untuk membuat persamaan atau model matematis dari representasi lain yang diberikan dan mampu menyelesaikan masalah dengan menggunakan ekspresi matematis.

Berdasarkan hasil analisis data pretes yang telah dilakukan terhadap kelas eksperimen dan kelas kontrol, diperoleh bahwa nilai pretes kedua kelas berdistribusi normal dengan taraf signifikansi 0,168 untuk kelas eksperimen yang menggunakan model pembelajaran CORE dan 0,442 untuk kelas kontrol yang menggunakan model pembelajaran langsung. Setelah data diuji normalitasnya maka selanjutnya diuji homogenitas. Dari data diperoleh nilai signifikansi uji homogenitas untuk kedua kelas adalah 0,880 sehingga dapat disimpulkan bahwa kedua kelas memiliki varians yang sama atau homogen. Untuk memastikan bahwa kedua kelas memiliki kemampuan awal yang sama maka dilakukan uji kesamaan dua rerata yaitu uji-t. Diperoleh nilai signifikansi 0,181 artinya tidak terdapat perbedaan kemampuan representasi matematis awal antara kelas eksperimen dan kelas kontrol. Hal tersebut karena siswa pada kedua kelas belum diberikan pembelajaran mengenai materi kubus dan balok. Setelah proses pembelajaran dilakukan, peneliti memberikan postes dengan soal yang sama seperti yang diberikan ketika pretes.

Setelah dilakukan postes pada kedua kelas kemudian peneliti melakukan perhitungan nilai $\mathrm{N}$-Gain untuk melihat peningkatan kemampuan representasi matematis siswa baik pada kelas eksperimen maupun pada kelas kontrol. Kemampuan representasi matematis siswa dapat terlihat dari jawaban siswa pada soal postes. Berikut adalah analisis jawaban postes siswa kelas eksperimen untuk salah satu indikator kemampuan representasi yaitu pada aspek representasi teks tertulis disajikan pada Gambar 2 dan Gambar 3.

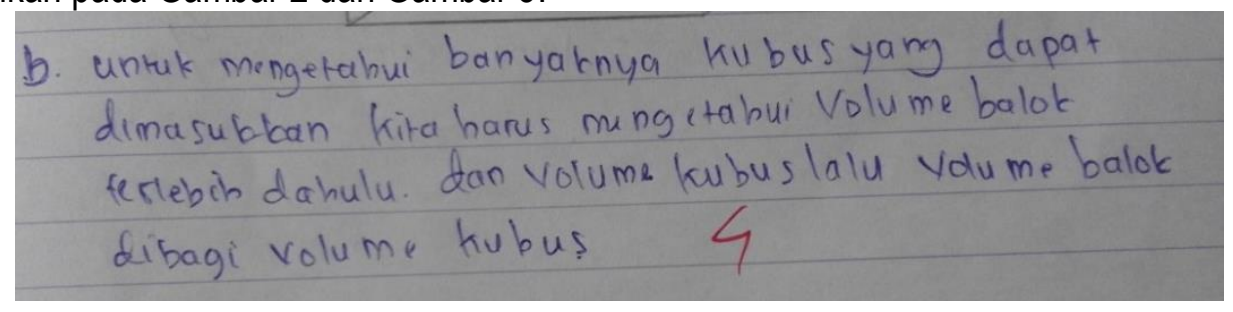

Gambar 2. Contoh Jawaban Indikator Representasi Teks Tertulis Siswa 1 


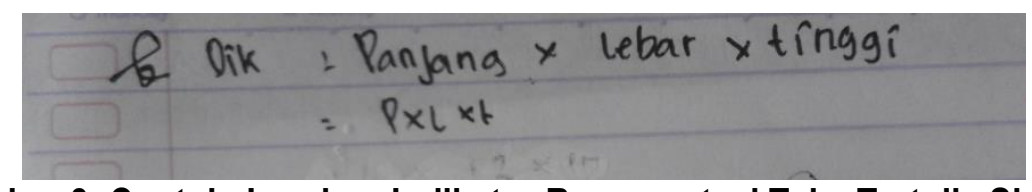

\section{Gambar 3. Contoh Jawaban Indikator Representasi Teks Tertulis Siswa 2}

Pada Gambar 2 terlihat bahwa siswa sudah mampu memberikan penjelasan mengenai cara penyelesaian dari permasalahan yang diberikan secara logis dan matematis. Sementara Gambar 3 siswa salah memahami apa yang diperintahkan dalam soal, dimana siswa tidak menuliskan penjelasan melainkan menuliskan rumus.

Peningkatan kemampuan representasi matematis siswa dapat dilihat dengan cara menganalisis data $\mathrm{N}$-Gain. Sebelum data $\mathrm{N}$-Gain dianalisis terlebih dahulu diuji secara deskriptif dengan hasil yang ditunjukkan pada Tabel 2, diperoleh nilai rata-rata 0,727 untuk kelas eksperimen yang menunjukkan bahwa peningkatan kemampuan representasi matematis siswa yang menggunakan model pembelajaran CORE termasuk kriteria tinggi. Peningkatan kemampuan representasi matematis siswa secara individual disajikan pada Tabel 4.

Tabel 4. Klasifikasi N-Gain Kelas Eksperimen Kemampuan Representasi Matematis Siswa

\begin{tabular}{ccc}
\hline Banyak siswa & Persentase & Kriteria \\
\hline 13 & $44,8 \%$ & Tinggi \\
15 & $51,7 \%$ & Sedang \\
1 & $3,45 \%$ & Rendah \\
\hline
\end{tabular}

Berdasarkan Tabel 4 menunjukkan bahwa pembelajaran dengan menggunakan model pembelajaran CORE dapat meningkatkan kemampuan representasi matematis siswa dengan kriteria tinggi sebanyak 13 orang, sedang sebanyak 15 orang dan rendah sebanyak 1 orang. Peningkatan nilai tes dipengaruhi oleh penggunaan model pembelajaran CORE. Model pembelajaran CORE dinilai dapat meningkatkan kemampuan representasi matematis siswa karena dalam model ini selama proses pembelajaran siswa berperan aktif untuk mengonstruksi pengetahuannya melalui pengungkapan gagasan maupun ide-ide dari suatu permasalahan yang diberikan oleh guru baik dalam bentuk bahan ajar maupun LKS. Adanya perbedaan peningkatan kemampuan representasi matematis siwa dapat dilihat dari hasil uji perbedaan dua rerata nilai $N$-Gain dengan uji MannWhitney yang diperoleh nilai signifikansi 0,000 yang artinya $H_{0}$ ditolak dan dapat disimpulkan bahwa terdapat perbedaan peningkatan kemampuan representasi matematis antara siswa yang menggunakan model pembelajaran CORE dengan siswa yang menggunakan model pembelajaran langsung.

Hasil penelitian ini sejalan dengan penelitian yang dilakukan oleh Hariyanto (2016) melakukan penelitian di MAN 2 Jember. Hasil perhitungan postes dianalisis menggunakan uji-t, diperoleh t-hitung 5,4025 > t-tabel 2,0150. Hasil belajar siswa yang menggunakan model pembelajaran CORE (kelas eksperimen) lebih baik daripada yang menggunakan pembelajaran konvensional (kelas kontrol). Sedangkan kemampuan komunikasi matematik kelas eksperimen lebih baik dari pada kelas kontrol, indikator rata-rata kemampuan tersebut adalah: (1) menulis, kelas ekperimen $(77,12)>$ dari kelas kontrol $(64,42)$; (2) menggambar, kelas eksperimen $(81,28)>$ kelas kontrol (74,36); (3) ekspresi matematika, kelas eksperimen $(82,82)>$ kelas kontrol $(78,21)$. Berdasarkan hasil pengolahan secara statistik, diperoleh kesimpulan bahwa peningkatan prestasi dan kemampuan komunikasi matematis siswa yang memperoleh model pembelajaran CORE lebih baik dari pada siswa yang memperoleh pembelajaran konvensional dan sebagian besar siswa menunjukkan sikap yang positif terhadap pembelajaran matematika dengan menggunakan model CORE yang telah dilakukan. Salah satu faktor yang dapat meningkatkan prestasi siswa adalah faktor kematangan dan informasi dari pengalaman berkontribusi terhadap pertumbuhan kognitif 
Zakiah \& Fajriadi (2020d). Jadi dapat disimpulkan bahwa model pembelajaran CORE dapat digunakan untuk meningkatkan kemampuan matematis siswa.

\section{KESIMPULAN}

Berdasarkan hasil penelitian, pengolahan data dan pengujian hipotesis yang telah dikemukakan, maka hasil dari penelitian ini dapat disimpulkan bahwa: (a) terdapat perbedaan peningkatan kemampuan representasi matematis siswa antara siswa yang menggunakan model pembelajaran CORE dengan siswa yang menggunakan model pembelajaran langsung; (b) kualitas peningkatan kemampuan representasi matematis siswa untuk kelas yang menggunakan model pembelajaran CORE termasuk kedalam kategori tinggi sedangkan kualitas peningkatan kemampuan representasi untuk kelas yang menggunakan model pembelajaran langsung termasuk kedalam kategori sedang.

\section{REKOMENDASI}

Dalam implementasi model pembelajaran CORE, sebaiknya guru membuat skenario dan perencanaan yang matang, sehingga pembelajaran dapat terjadi secara sistematis sesuai rencana dan waktu dapat dimanfaatkan secara efektif. Serta bagi peneliti selanjutnya, hendaknya penelitian mengenai model pembelajaran CORE dilakukan lebih luas khususnya untuk kemampuan representasi matematis siswa.

\section{UCAPAN TERIMAKASIH}

Ucapan terimakasih penulis sampaikan kepada Kepala SMP NEGERI 1 Baregbeg yang telah memberikan izin penelitian, kepada Ibu Yulia Misdiana Fitriani, S.Pd, selaku guru mata pelajaran matematika SMP Negeri 1 Baregbeg yang telah membantu selama proses penelitian. Tak lupa kepada seluruh siswa kelas VIII-I dan VIII-J yang telah menjadi sampel penelitian.

\section{DAFTAR PUSTAKA}

Arnidha, Y. (2016). Peningkatan kemampuan representasi matematis melalui model pembelajaran kooperatif think pair share. Jurnal Edumath, 1(2), 128-137. [Online]. Tersedia: http://download.portalgaruda.org/article.php [30 Januari 2018].

Dwijayanti, A., \& Kurniasih, A. W. (2014). Komparasi kemampuan pemecahan masalah matematika antara model PBI dan CORE materi lingkaran. Unnes Journal of Mathematics Education, 3(3), 190-195. [Online]. Tersedia: http://journal.unnes.ac.id/sju/ index.php/ujme [28 januari 2018].

Elida, N. (2012). Meningkatkan kemampuan komunikasi matematik siswa sekolah menengah pertama melalui pembelajaran think talk write (TTW). Jurnal IImiah Program Studi Pendidikan Matematika STKIP Siliwangi Bandung, 1(2), Tersedia: http:/lejournal.stkipsiliwangi.ac.id/index.php/infinity/article/view/17/16 [4 Februari 2018].

Hariyanto. (2016). Penerapan model CORE dalam pembelajaran matematika untuk meningkatkan kemampuan komunikasi matematik siswa. Jurnal Gammath, 1(2), 33-40. [Online] . Tersedia: http://jurnal.unmuhjember.ac.id/index.php/JPM/article/download /462/352 [31 januari 2018].

Legi, M. Y. (2008). Kemampuan representasi matematis siswa sd kelas iv melalui pendidikan matematika realistik pada konsep pecahan dan pecahan senilai. [Online]. Tersedia: http://karyailmiah.um.ac.id/index.php/disertasi/article/view/899 [1 Februari 2018].

National Council of Teachers of Mathematic. (2000). Principles and standards for school mathematics. Reston: NCTM. 
Nurhayati, Y., Zakiah, N. E., \& Amam, A. (2020). Integrasi contextual teaching learning (ctl) dengan geogebra: dapatkah meningkatkan kemampuan koneksi matematis siswa?. Teorema: Teori dan Riset Matematika, 5(1), 27-34. DOI: http://dx.doi.org/10.25157/teorema.v5i1.3349.

Shoimin, A. (2014). 68 model pembelajaran inovatif dalam kurikulum 2013. Yogyakarta: Ar-Ruz Media.

Sugiyono. (2016). Metode penelitian kuantitatif, kualitatif, dan R\&D. Bandung: Alfabeta.

Suryowati, E. (2015). Kesalahan siswa sekolah dasar dalam merepresentasikan pecahan pada garis bilangan. Aksioma Jurnal Pendidikan Matematika, 4(1), 38-52. [Online]. Tersedia: https://www.researchgate.net/publication/314981883 [31 Januari 2018].

Zakiah, N. E. (2017). Pembelajaran dengan pendekatan kontekstual berbasis gaya kognitif untuk meningkatkan kemampuan metakognitif siswa. Pedagogy, 2(2), 11-29. DOI: http://dx.doi.org/10.30605/pedagogy.v2i2.700.

Zakiah, N. E., Sunaryo, Y., \& Amam, A. (2019). Implementasi pendekatan kontekstual pada model pembelajaran berbasis masalah berdasarkan langkah-langkah polya. Teorema: Teori dan Riset Matematika, 4(2), 111-120. DOI: http://dx.doi.org/10.25157/teorema.v4i2.2706.

Zakiah, N. E., \& Fajriadi, D. (2020a). Hybrid-PjBL: creative thinking skills and self-regulated learning of preservice teachers. J. Phys.: Conf. Ser. 1521 032072. doi:10.1088/1742$6596 / 1521 / 3 / 032072$.

Zakiah, N. E., Fatimah, A. T., \& Sunaryo, Y. (2020c). Implementasi project-based learning untuk mengeksplorasi kreativitas dan kemampuan berpikir kreatif matematis mahasiswa. Teorema: Teori dan Riset Matematika, 5(2), 285-293. DOI: http://dx.doi.org/10.25157/teorema.v5i2.4194.

Zakiah, N. E., Fatimah, A. T., Sunaryo, Y., \& Amam, A. (2020d). Collaboration and communication skills of pre-service mathematics teacher in designing project assignments. J. Phys.: Conf. Ser. 1657 012073. doi:10.1088/1742-6596/1657/1/012073.

Zakiah, N. E., \& Fajriadi, D. (2020b). Self regulated learning for social cognitive perspective in mathematics lessons. J. Phys.: Conf. Ser. 1613 012049. doi:10.1088/17426596/1613/1/012049. 
